University of South Florida

DIGITAL COMMONS

Digital Commons @ University of

@ UNIVERSITY OF SOUTH FLORIDA

South Florida

KIP Articles

KIP Research Publications

March 2009

\title{
A cavernicolous Species of the Genus Anelpistina (Insecta: \\ Zygentoma: Nicoletiidae) from Naj Tunich Cave, Petén, Guatemala
}

Follow this and additional works at: https://digitalcommons.usf.edu/kip_articles

\section{Recommended Citation}

"A cavernicolous Species of the Genus Anelpistina (Insecta: Zygentoma: Nicoletiidae) from Naj Tunich Cave, Petén, Guatemala" (2009). KIP Articles. 786.

https://digitalcommons.usf.edu/kip_articles/786

This Article is brought to you for free and open access by the KIP Research Publications at Digital Commons @ University of South Florida. It has been accepted for inclusion in KIP Articles by an authorized administrator of Digital Commons @ University of South Florida. For more information, please contact digitalcommons@usf.edu. 
PROC. ENTOMOL. SOC. WASH.

111(3), 2009, pp. 575-580

\title{
A CAVERNICOLOUS SPECIES OF THE GENUS ANELPISTINA (INSECTA: ZYGENTOMA: NICOLETIIDAE) FROM NAJ TUNICH CAVE, PETÉN, GUATEMALA
}

\author{
Luis Espinasa ANd Zhong ZhuAng
}

(LE) Department of Biology, Marist College, 3399 North Road, Poughkeepsie, New York 12601 (e-mail: luis.espinasa@marist.edu, espinasl@yahoo.com); (ZZ) John Jay Senior High School, Hopewell Junction, New York 12533

Abstract. - Anelpistina levidensis n. sp. (Insecta: Zygentoma: Nicoletiidae) from the cave of Naj Tunich, Petén, Guatemala is described. The new troglobitic species differs from other described species by its long and slim appendages.

Key Words: Cubacubaninae, bristletail

Adaptations to caves include reduction of mass, flattening of body, blindness, loss of pigmentation, and elongation of body parts to account for darkness and food scarcity (Hüppop 2004). Specifically, the elongation of appendages increases the sensitivity of an insect to the landscape and food around it (Hüppop 2004). The new species described here has become strongly adapted to cave life. It is the species with the longest and slimmest appendages within the subfamily Cubacubaninae.

\section{Materials And Methods}

Individuals were originally collected by G. Veni and A. Cobb and deposited in the collection of the Texas Memorial Museum of Invertebrate Zoology. The four individuals used in this study were found in two vials of ethanol. Dissections were made with the aid of a stereo microscope. Male holotype mouth parts and genital area were mounted in fixed preparations with solution. Remaining male and female samples were left in a vial with ethanol. All illustrations were

\footnotetext{
* Accepted by David R. Smith
}

made with aid of a camera lucida attached to a compound microscope.

\section{Anelpistina levidensis Espinasa and Zhuang, new species \\ (Figs. 1A-F, 2A-F)}

Type material.-Male holotype (body $11 \mathrm{~mm}$, antennae $27 \mathrm{~mm}$, caudal appendages $23 \mathrm{~mm})$, one male paratype $(10 \mathrm{~mm}$, $30 \mathrm{~mm}$, caudal appendages broken), two female paratypes $(12 \mathrm{~mm}, 36 \mathrm{~mm}, 20 \mathrm{~mm}$ \& $14 \mathrm{~mm}$, antennae broken, $33 \mathrm{~mm}$ ). Guatemala, Petén, Actún Naj Tunich, Poptún. 2-10/04/1989, cols G. Veni \& A. Cobb. Texas Memorial Museum Invertebrate Zool. Coll. \#23,602. Will be deposited in the American Museum of Natural History, New York, NY.

Description.-Maximum body length $14 \mathrm{~mm}$. Maximum conserved length of antenna $36 \mathrm{~mm}$. Maximum conserved length of caudal appendages $33 \mathrm{~mm}$. When complete, antennae 3-4× length of body and caudal appendages $2.5 \times$ length of body (Fig. A). General color light yellow to white.

Head with macrochaetae and microchaetae as shown in Fig. 1B, macrochae- 

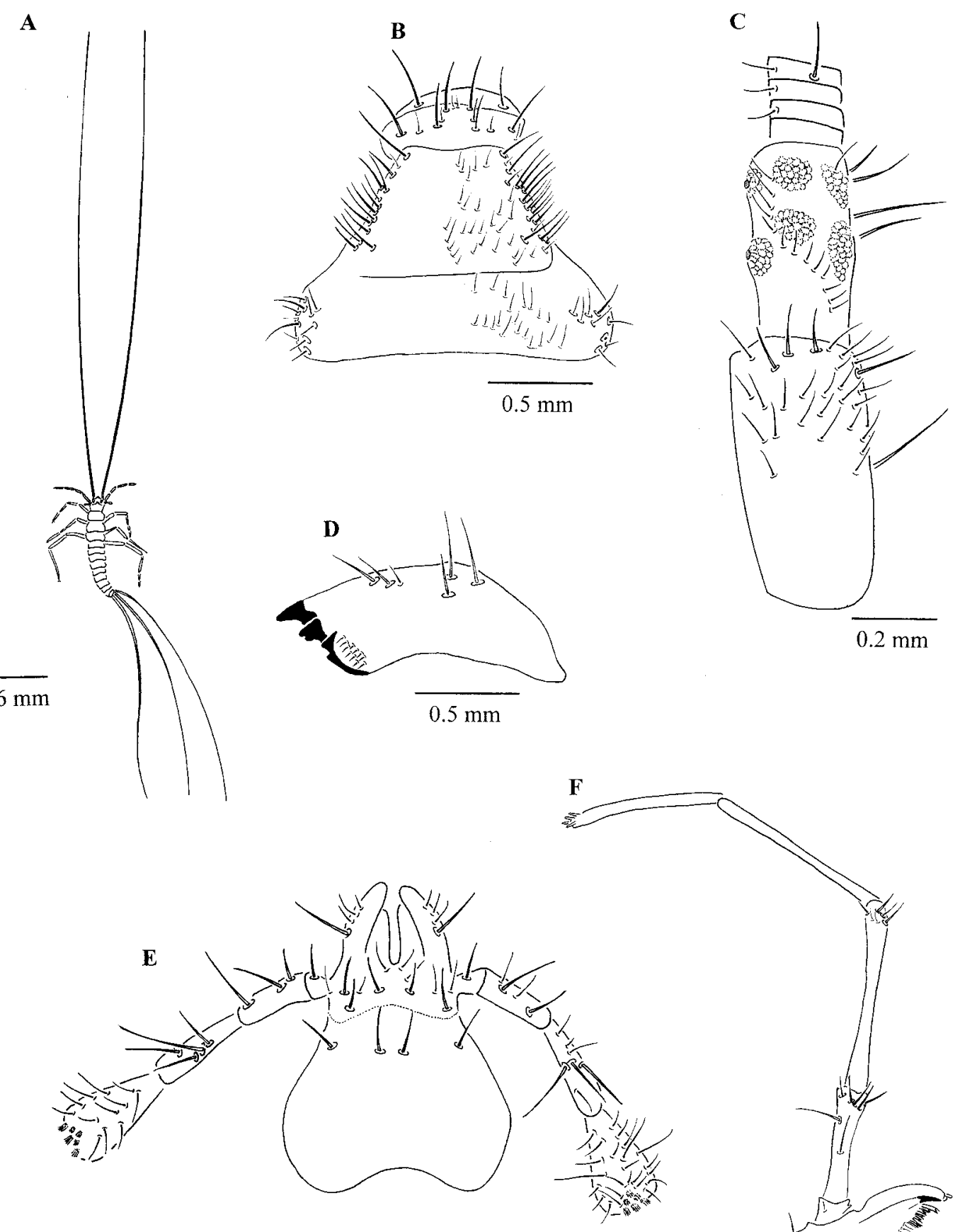

$\overline{0.3 \mathrm{~mm}}$

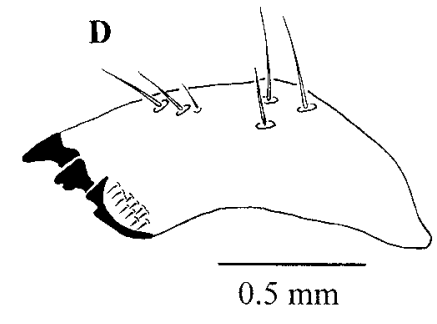

\section{${ }^{F}$}
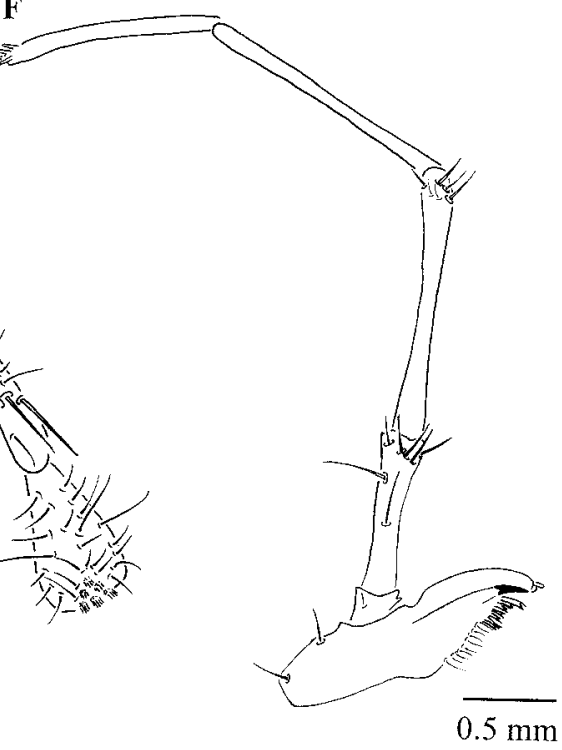

Fig. 1. Anelpistina levidensis, n. sp. A, Female paratype. B-F, Male holotype. A, Body proportions. B, Head. C, Basal portion of antenna. D, Mandible. E, Labium. F, Maxilla. 
A
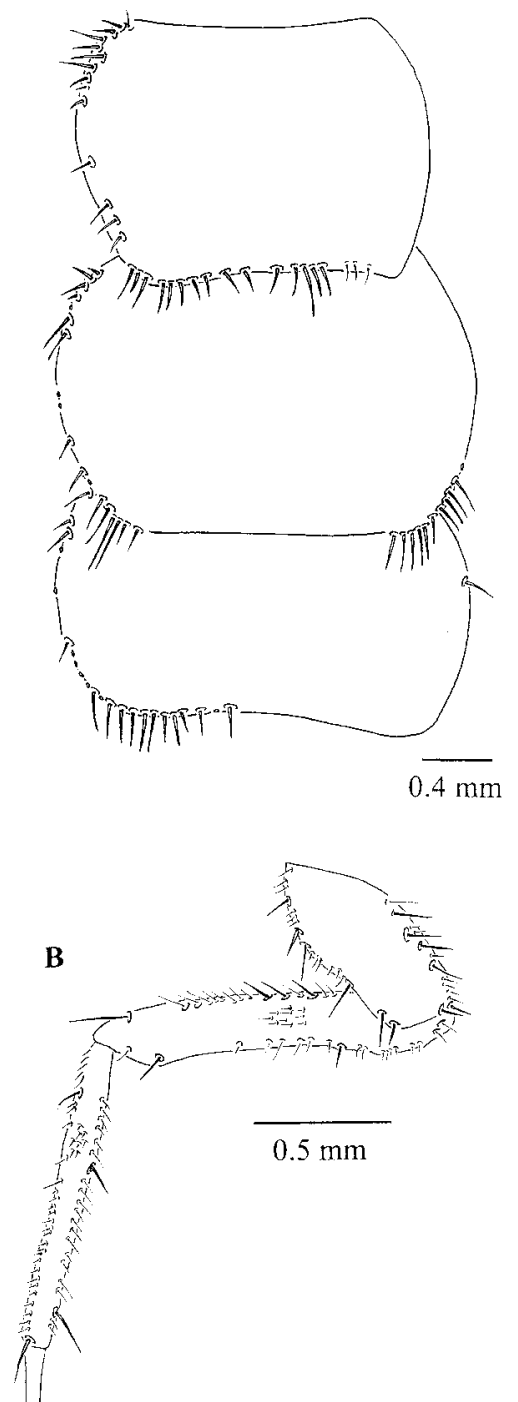

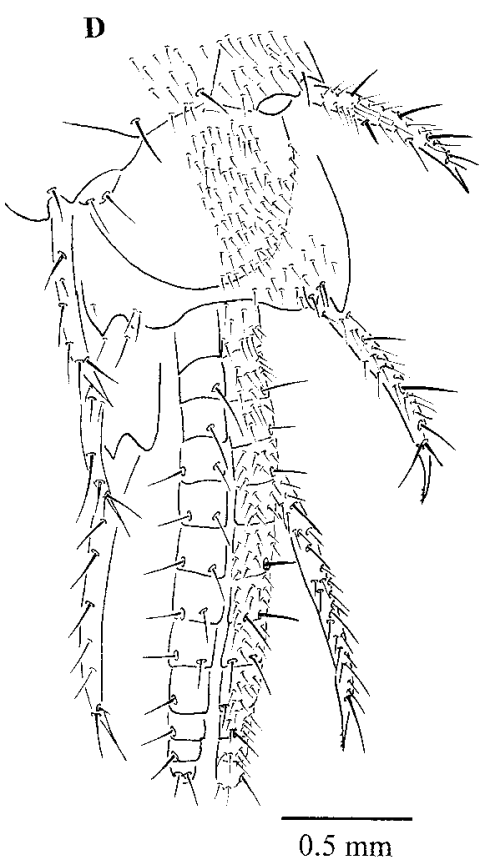

C
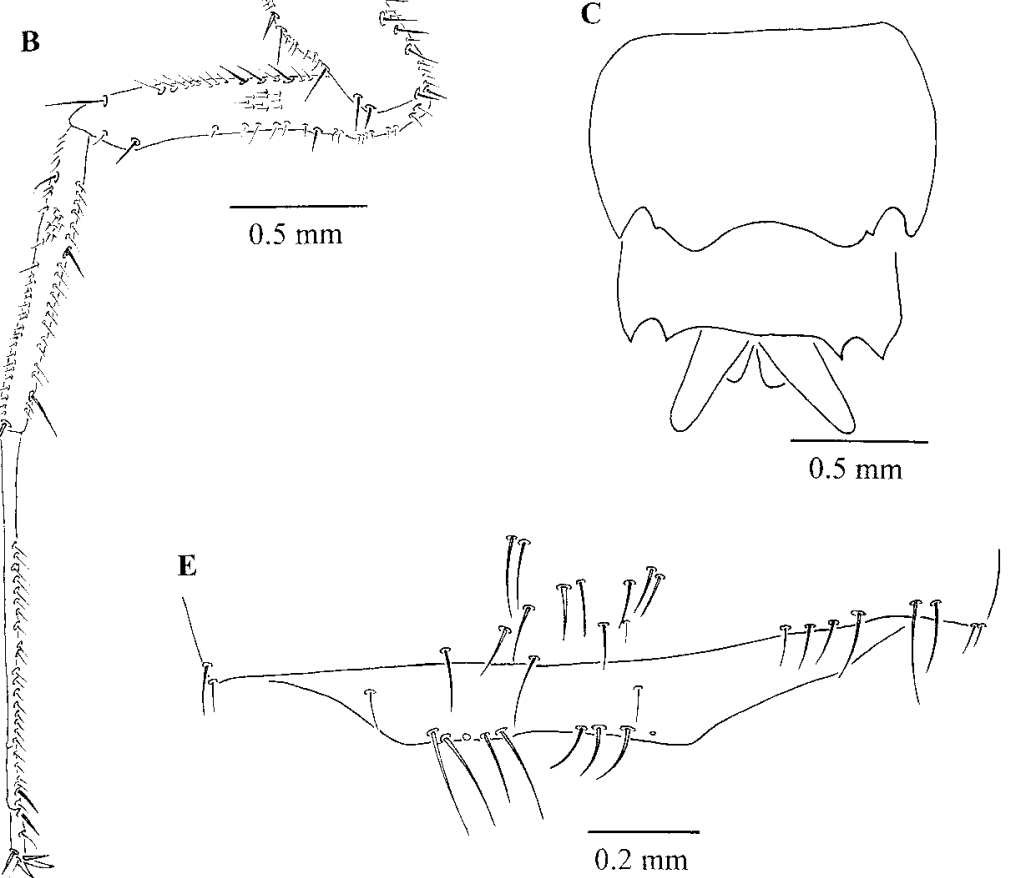

$\mathbf{F}$

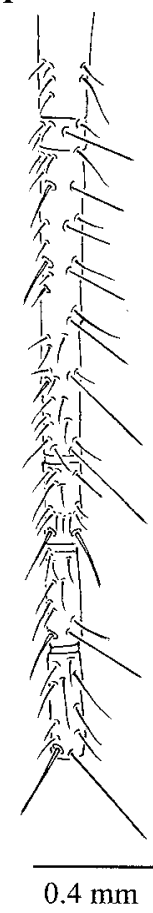

Fig. 2. Anelpistina levidensis n. sp. A-C, E-F, Male holotype. D, Female paratype. A, Thoracic nota. B, Hind leg. C, Genital area. D, Ovipositor and subgenital plate. E, Urotergite X. F, Cercus. 
tae on border of insertion of antenna very abundant. Basal articles of antenna very long. In males, both first article and pedicellus length are $2 \times$ their width. Pedicellus length $3 / 4$ of first article. Pedicellus with unicellular glands on ventral surface, clustered approximately in four groups and with a row of microchaetae bordering them in form of a "U" (Fig. 1C). On outside lateral border, an extra pair of clusters (Fig. 1C). In females, pedicellus shorter. Its length $1 / 2$ of first article.

Mandible chaetotaxy as in Fig. 1D, with five macrochaetae; the four standard macrochaetae of other Anelpistina species, plus an extra beside the distal macrochaetae. Mouthparts extremely long. Labial palp as in Fig. 1E, apical article almost $2 \times$ longer than wide. Apical article equal in length to penultimate article. Penultimate article very slim, $3.5 \times$ longer than wide and without prominent bulge. Labium and first article of labial palp with macrochaetae. Labium with one distinctly longer macrochaetae. Maxilla extremely long and slim as shown in Fig. 1F. Ultimate article of maxillary palp approximately $4 / 5$ the length of penultimate article. Penultimate article $14 \times$ longer than wide. Apex of galea with two conules of different widths. Two teeth on lacinia plus a third thin hyaline one between them.

Mesonotum with numerous macrochaetae and setae of varied sizes (Fig. 2A). Legs extremely long as shown in Fig. 2B. Hind tibia approximately $10 \times$ longer than wide and 3/4 length of tarsus. Tarsus $30 \times$ longer than wide. Claws relatively long and smooth, without a hairy appearance, similar to $A$. mexicana as illustrated in Espinasa et al. (2007).

Abdominal terga and sterna as in other members of genus. Abdominal sterna IIVII subdivided into coxites and sternites. Sterna VIII and IX of male entire. Chaetotaxy of sternites with median portion of sternites with $1+1$ sublateral macrochaetae at posterior hind borders (Fig. 2D), but without $1+1$ macrochaetae near suture at about middle of segment. Appendages of urosternum III and IV of male apparently without modifications. Urosternum VIII of male long and shallowly emarginate on posterior margin (Fig. 2C). Urosternum IX of male as in Fig. 2C. Point of insertion of parameres in urosternum IX shallow and straight, almost level with base of stylets of this segment. Urosternum IX centrally and on coxal processes without any apparent thicker or sclerotized setae.

Stylets IX larger than others, with 4-5 macrochaetae and an extra subapical pair (Fig. 2D). One of the subapical pair distinctly larger than other. Terminal spine very slim, long, and pointed, with small teeth (Fig. 2D). Stylets IX in males broken. Stylets IX in females without modifications.

Penis and parameres as shown in Fig. 2C. Parameres assumed to attain about $1 / 3$ length of stylets IX (stylets IX were broken so size is given in proportion with other stylets). Subgenital plate of female rounded to parabolic (Fig. 2D). Ovipositor in adult females slightly surpassing apex of stylets IX (Fig. 2D). Gonapophyses with approximately 12 annuli.

Urotergite $\mathrm{X}$ almost straight on posterior edge in both sexes (Fig. 2E), and even slightly convex in some specimens. Posterior margin with multiple macrochaetae of various sizes (Fig. 2E). Cercus of adult male with a longer than wide basal article followed by a shorter than wide, then a very long article, followed by numerous short articles of simple chaetotaxy. No spines on largest male specimen $(11 \mathrm{~mm})$ although this may have been due to its young postembrionic development (Fig. 2F). Female cercus simple.

Postembryonic development mostly unknown; males measured $10 \mathrm{~mm}$ to $11 \mathrm{~mm}$ and both had glands on the pedicellus. Their genital area and cerci were simple. It 
is likely that both are juvenile and that larger males will have further modifications. As for the females, they measured $12 \mathrm{~mm}$ and $14 \mathrm{~mm}$ and in both, genital areas were identical. As with other species, younger individuals may have a reduction of secondary sexual characters.

Distribution.--Known only from type locality.

Etymology.-levidensis (Nominative, singular, masculine). Latin for thin, slight or slender. Referring to its long and slim appendages. It is the species within the Cubacubaninae with the longest and most slender antennae, mouthparts, and legs.

Remarks.-The new species described here is a member of the subfamily Cubacubaninae. It has stylets on urosternite II, but lacks scales or sensory pegs in the appendix dorsalis and conspicuous lateral lobes bearing numerous glandular pores. As such, its generic allocation is within Anelpistina Silvestri, 1905 (= Cubacubana Wygodzinsky and Hollinger, 1977; = Neonicoletia Paclt, 1979) as defined by Espinasa et al. (2007).

Anelpistina levidensis can be differentiated from all other members of the genus because its appendages are the longest and most slender in the group (labial palp almost $2 \times$ longer than wide, hind tibia approximately $10 \times$ longer than wide, and antennae up to $4 \times$ length of body). The new species also has a set of characters found in just a few species of the genus Anelpistina, but present in other genera of the subfamily: (a) a smooth endopodium and lateral claws, present only in Prosthecina, Squamigera, Anelpistina mexicana (Espinasa 1991) and Anelpistina yatbalami Espinasa, 2007 (b) stylets IX with 4-5+2 macrochaetae, found only in Prosthecina, Squamigera, Anelpistina mexicana and Anelpistina asymmetrica (c) point of insertion of parameres in urosternum IX shallow, almost level with the base of stylets of this segment, present only in Prosthecina, Anelpistina mexicana and Anelpistina asymmetrica (Espinasa 2000).
In 2007, Espinasa et al. studied the relationships within the subfamily Cubacubaninae, the dominant subfamily of Nicoletiidae in America, based on morphology and sequence data from five loci. In one of their two most parsimonious trees, $A$. mexicana, $A$. asymmetrica, and $A$. yatbalami appear as the three most basal species of genus Anelpistina, just after the group separated from genus Prosthecina and Squamigera. It is likely that $A$. levidensis has phylogenetic relationships within this group. Clarification of its position within this paraphyletic group will require further molecular studies. Anelpistina levidensis has 12 annuli on the gonapophyses, which makes it easy to differentiate from $A$. asymmetrica with 17 annuli, A. mexicana with 21 , and A.yatbalami with at least 15 . The single female described for this species was a juvenile, so the final number of annuli was not yet developed, but it is certainly more than 15 .

\section{ACKNOWLEDGMENTS}

We thank James Reddell for allowing us to study the Nicoletiid material from the Texas Memorial Museum Invertebrate Zoology Collection. We also thank Michael Tannebaum, Dean of the School of Sciences, for the support to publish this manuscript.

\section{Literature Cited}

Espinasa, L. 1991. Descripción de una nueva especie del género Cubacubana (Zygentoma: Nicoletiidae) y registro del género para América Continental. Folia Entomológica Mexicana 82: 5-16. . 2000. A new species of the genus Cubacubana (Insecta: Zygentoma: Nicoletiidae) from a Mexican cave. Proceedings of the Biological Society of Washington 113(1): 218-223.

Espinasa, L., C. Flick, and G. Giribet. 2007. Phylogeny of the American silverfish Cubacubaninae (Hexapoda: Zygentoma: Nicoletiidae): A combined approach using morphology and five molecular loci. Cladistics 23(1): 22-40.

Hüppop, K. 2004. Adaptation to food, pp. 4-10. In Culver, D. C. and W. B. White, eds. Encyclopedia of Caves. Elsevier Academic Press, $680 \mathrm{pp}$. 
Paclt, J. 1979. Neue Beiträge zur Kenntnis der Apterygoten-Sammlung des Zoologischen Instituts und Zoologischen Museums der Universität Hamburg. VI Weitere Doppel- und Borstenschwänze (Diplura: Campodeidae, Thysanura: Lepismatidae und Nicoletiidae). Entomologische Mitteilungen aus dem Zoologischen Museum Hamburg 6: 221-228.
Silvestri, F. 1905. Materiali per lo studio dei Tisanuri. VI. Tre nuove specie di Nicoletia appartenenti ad un nuovo sottogenero. Redia (Firenze) 2: 111-120.

Wygodzinsky, P. and A. M. Hollinger. 1977. A study of Nicoletiidae from Cuba (Thysanura). Resultats des Expéditions Biospeleologiques Cubano-roumaines à Cuba 2: 313-324. 